ment in 1942. Following this he served from 1942 to 1945 on the staff of the Muncipal Hospitals of Winnipeg. Dr. Speechly passed away on March 17, 1951.

Dr. Speechly was a moving spirit in the Manitoba Horticultural Association and was one of the founders of the Natural History Society and of the Manitoba Museum. For 25 years he and his associates worked tirelessly to convince the authorities and the general public that mosquito control was a practical and greatly needed health measure. When the 1950 flood threatened to endanger the health of the citizens, the mosquito abatement organization was ready to swing into action.

Dr. Speechly was a widely read man of tremendous energy and en- thusiasm, an able speaker, interested in bettering conditions wherever he happened to be. All down the years, both Dr. and Mrs. Speechly were originators of new, practical ideas, far-seeing and interested in the welfare of the general public. More than that, they were prepared to follow up each new venture with sustained enthusiasm and sheer hard work.

In recognition of a life-time of voluntary service to the Province of Manitoba, the University of Manitoba honoured Dr. Speechly on May 14,1943 , by conferring on him the degree of LL.D. On October 15, 1947, the same honour was bestowed on Mrs. Speechly for her outstanding contributions in the fields of education and public welfare.

\title{
Self-guided Nature Trails Established in Cypress Hills Park
}

\author{
by Douglas E. Wade1, Regina
}

Self-guided nature trails, whereon you can walk without personal guide, have been in use in North America since the 1920's. Such trails, an accepted part of interpretive programs of national parks, are rare in Canadian provincial parks. There are many varieties of "marked" nature trails ranging from those that simply label plants in season along a pathway to those that lead the viewer to an understanding of how nature works through its many inter-relationships. The latter style is much more difficult to construct.

Recently, three nature trails have been developed at Cypress Hills Provincial Park." Two are "selfguided" nature trails and mimeographed "guide" information for each can be obtained at park headquarters. The other trail, perhaps unique in Canada, is a combined "nature and compass trail." To use it one must not only know something about natural history but also how to use a compass and make linear measurements up and down hill and on the level by pacing. A mimeographed set of instructions for this compass route is also available at park headquarters.
The compass trail, because it culminating point of interest is a group of old buffalo wallows, has been named "Plateau of the Buffalo Wallows." The other trails, each named after a distinctive feature, are "Valley of the Beavers" and "Valley of the Windfalls."

The "Valley of the Beavers" trail starts from the east end of the dam forming Loch Lomond and wends southward down the left bank of the Lone Pine Creek for about eighttenths of a mile. It then crosses the creek by a low foot bridge immediately below and parallel to a 100 -foot beaver dam. The trail then goes back up the valley along the right bank of the creek recrossing the creek by a foot bridge and back to the starting point. From near the Lone Pine Camp Ground, there is an auxiliary entrance route. The entire trail has 22 marked stations or points of interest. Each station (a numbered stub post) covers some characteristic actions and relationships of beavers to their environment.

Beaver workings and "signs" along the valley are very abundant. During early morning and late evening 
hours it is quite possible-if one is quiet-to observe beavers in the several ponds. Opportunities for still and motion picture photography of beavers and other wildlife are excellent at many places along the valley. Many other kinds of wildlife can be sighted or discovered by "sign" in the valley.

The floral displays of the valley are vivid and constant throughout the growing season, from the pastel colors of early spring to the flaming golds of the aspen in the fall.

All wildlife, both plants and animals, are given full protection along the trail. This, of course, is a basic ground rule to insure the continued richness of the valley. For here is truly a beautiful valley. Once the scars of getting a trail and markers established have healed, it will be up to each individual user to abide by the simple ground rules and refrain from dropping litter along the trail.

The other self-guided nature trail in Cypress Park has been named "Valley of the Windfalls." This trail is only three-tenths of a mile from the main centre of activities of the park and stems off the Boiler Trail road winding through a valley and a lodgepole-pine upland for a total length of about eight-tenths of a mile. The valley contains large white spruce many of which have been blown over by high winds. Because of a high water table throughout the valley, the trees have very shallow roots. Although there is a criss-cross welter of downed trees here and there in the valley, the authorities have indicated there will be no clcanup work done. The scene, aside from keeping the trail free of debris and dangerous, leaning trees, will be kept as it is.

Many red squirrels inhabit Windfall Valley and white-tailed deer have been regularly spooked from the valley. Deer trails are frequent and the nature trail itself follows in part active "game" trails. At one station, you can see the claw marks of a bobcat on a small aspen and in another place, you can observe how buck deer have shredded the bark of willows while removing velvet from their antlers. There are 35 stub-post numbered stations along the "Valley of the Windfalls."

On each of the trails the walker will get some identification, life history facts, ecology, and perhaps some applied ecology (management).

A major concept underlying the establishment of these trails, which were laid out under the supervision of the Conservation Information Service of the Department of Natural Resources, is expressed in a recent definition of "conservation" by Arthur Carhart: "Conservation is thought and action directed by man to protect, maintain and fortify the environmental complex that supports and enriches life as it now exists on the planet earth."

The key to Mr. Carhart's definition lies in an understanding of the "environmental complex." These nature trails can bring a bit of understanding to the trail walker of what is meant by "environmental complex" and how important it is to save the environment that makes up the dwelling places for many kinds of wild plants and creatures.

The trails themselves lead you through areas of beauty and richness. There is, of course, always the danger that by establishing such traiks this beauty and richness will ultimately be destroyed by those who refuse to observe a few simple protective ground rules. We hope that this will not happen in the Cypress Hills Park, for these three irails represent a pioneering effort in Saskatchewan's provincial parks.

1 Formerly Supervisor, Conservation Information Service, Department of Natural Resources, Mr. Wade resigned frum this position July 12, 1963.

2 The writer wishes to acknowledge the very considerable field assistance given by Mr. Peter Gregg of La Ronge, the aid of the Cypress Hills Park staff, the field work done voluntarily by his own son, Alan Wade, and friend Jim Sekulich, and the co-operation of Art Hartwell, Superintendent of Southern Region, Department of Natural Resources, who encouraged the project and expedited the establishing of the trails and the preparation of the signs. 